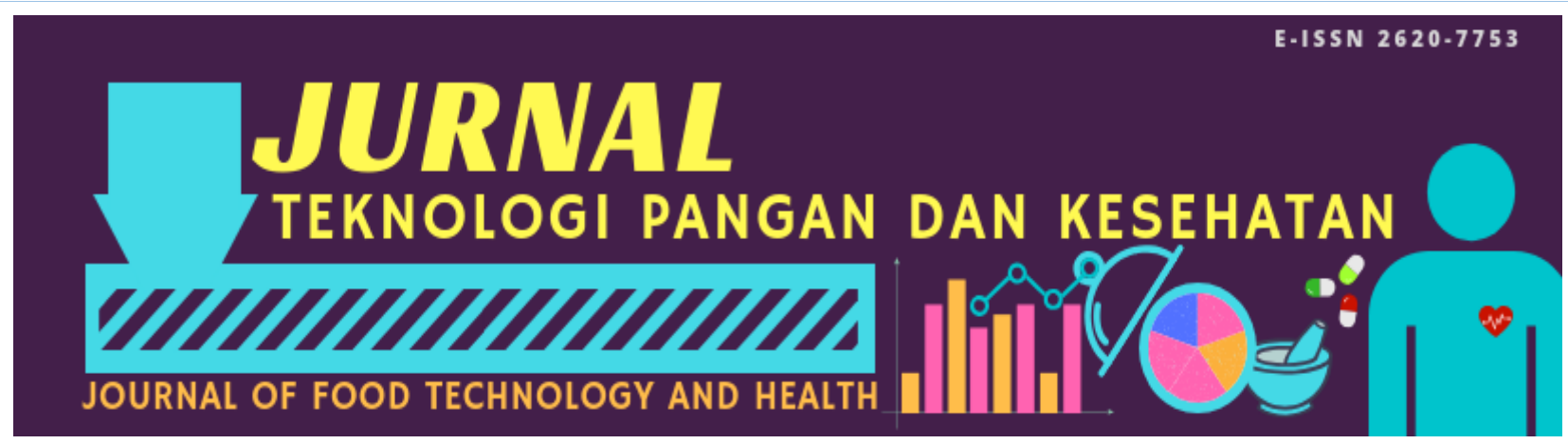

Volume I Nomor I Tahun 2019

Hasil Penelitian

Diterima 6 Feb 2019

Disetujui 29 Mei 2019

\title{
MUTU MIKROBIOLOGIS UDANG SELAMA PENYIMPANAN DALAM KEMASAN PLASTIK BIODEGRADABLE DENGAN MATRIKS DAMAR DAGING DAN PATI TAPIOKA
}

\author{
Iman Basriman ${ }^{1 *}$, Dahni Betto Harso ${ }^{2}$, Noryawati Mulyono ${ }^{2}$ \\ ${ }^{1}$ Universitas Sahid, Jakarta; ${ }^{2}$ Unika Atmajaya, Jakarta
}

\begin{abstract}
ABSTRAK: Shorea leprosula (damar daging) adalah salah satu tanaman yang dapat digunakan sebagai bahan baku pembuatan plastik biodegradable. Damar daging mengandung senyawa antimikroba sehingga plastik biodegradable yang dihasilkan juga memiliki sifat antimikroba. Untuk meningkatkan aktivitas antimikroba dalam plastik biodegradable dengan penambahan resin, bisa dilakukan penambahan bahan kimia lain yang juga bersifat antimikroba. Penelitian ini bertujuan untuk mengetahui pengaruh matriks resin daging dengan tepung tapioka dalam pelapis kemasan biodegradable dengan penambahan seng klorida, perak nitrat, propionat dan propil paraben, terhadap kualitas mikrobiologis udang yang dikemas untuk penyimpanan. Penelitian ini menggunakan rancangan acak lengkap faktorial $5 \times 5$ dengan dua pengulangan, faktor pertama adalah jenis kemasan biodegradable dengan 5 level perlakuan (pelapisan lesitin $+\mathrm{ZnCl}_{2}$, lesitin $+\mathrm{AgNO}_{3}, \mathrm{AgNO}_{3}$, kontrol positif, dan kontrol negatif), faktor kedua adalah waktu penyimpanan dengan 5 tingkat perlakuan $(0,2,4,6,8$ hari). Parameter kualitas yang diuji meliputi kadar air, jumlah lempeng total, Escherichia coli, Salmonella typhi dan Vibrio cholerae pada udang. Hasil penelitian menunjukkan bahwa penambahan resin kemasan pati, perak nitrat, dan lesitin selama 8 hari penyimpanan, menunjukkan kadar air menurun, sehingga dapat disimpulkan bahwa kemasan ini dapat mengurangi kadar air. Untuk pelapisan mikroba total, semua jenis kemasan dengan lesitin, seng klorida dan perak nitrat tidak menunjukkan perbedaan yang signifikan, tetapi berbeda secara signifikan dari kemasan kontrol positif dan negatif. Sedangkan untuk pengujian Eschericia coli, Salmonella typhi, Vibrio cholerae menunjukkan hasil kemampuan menahan pertumbuhan spesifik yang umum untuk semua jenis kemasan.
\end{abstract}

Kata Kunci: Shorea leprosula, antimikroba, biodegradable

ABSTRACT: Shorea leprosula (resin flesh) is one of the plants that can be used as raw material in the manufacture of biodegradable plastics because it contains antimicrobial compounds, biodegradable plastics produced also have antimicrobial properties. To enhance the antimicrobial activity in the biodegradable plastics with the addition of resin flesh, other chemicals being antimicrobial properties can be introduced. This study aims to determine the effect of the matrix of resin flesh with tapioca starch in biodegradable packaging coated with zinc chloride, silver nitrate, propionate, propyl paraben, on the microbiological quality of the shrimp packed for storage purposes. The experimental design employed in this study was completely randomized factorial $5 \times 5$ with two repetitions, in which the first factor was the biodegradable plastics matrix of tapioca starch and resin flesh with 5 levels of treatment (coating lecithin $+\mathrm{ZnCl}_{2}$, lecithin $+\mathrm{AgNO}_{3}, \mathrm{AgNO}_{3}$, the positive control, and negative control), and the second factor was storage period with 5 levels of treatment (day 0,2,4,6,8). Quality parameters observed were moisture content, total plate count, Escherichia coli, Salmonella typhi, Vibrio cholerae of shrimp. The results showed that the addition of resin, silver nitrate, and lecithin to starch packaging for 8 days storage, demonstrated decreasing moisture content, so that it can be concluded that this packaging can reduce the moisture content. Total microbial coating counts for all kinds of packaging with lecithin, zinc chloride and silver nitrate showed no significant results difference, but significantly different from positive and negative control packaging. Meanwhile Escherichia coli, Salmonella typhi, and Vibrio cholerae tests showed the ability to restrain the specific growth being common to all types of packaging.

Keywords: Shorea leprosula, antimicrobials, biodegradable

\footnotetext{
*Email korespondensi: imbasriman@yahoo.com
} 


\section{PENDAHULUAN}

Penggunaan kemasaan dengan aktivitas antimikroba merupakan salah satu solusi yang paling baik dalam mengatasi masalah pengawetan pangan. Selain tidak mengubah rasa dan tekstur pangan, cara pengawetan ini juga tidak melibatkan pangan secara langsung dengan penggunaan senyawa kimia sintetik. Namun, masalah yang dapat timbul dari cara pengawetan ini adalah penggunaan plastik yang berfungsi sebagai kemasan.

Plastik merupakan salah satu masalah terbesar dalam lingkungan. Hal ini terjadi karena penggunaan plastik sangat tinggi, sedangkan plastik tidak dapat didegradasi oleh mikroorganisme. Salah satu cara untuk mengatasi limbah plastik tersebut adalah penggunaan plastik biodegradable. Berbeda dengan plastik konvensional, plastik biodegradable merupakan plastik yang terbuat dari polimer yang dapat didegradasi oleh mikroorganisme, seperti: pati, kitosan, gluten, keratin, asam polilaktat, dan polihidroksi butirat, dan lain-lain. Plastik biodegradable dapat dibuat dari berbagai bahan baku yang memiliki komposisi pati yang cukup tinggi. Pati tapioka banyak digunakan pada industri pangan sebagai biodegradable film karena ekonomis, dapat diperbaharui dan memberikan karakteristik fisik yang baik (Bourtoom, 2007).

Harris (2001) telah menggunakan pati tapioka dalam pembuatan plastik biodegradable dan film yang dihasilkan memiliki karakteristik fisik yang cukup baik serta dapat digunakan sebagai pengemas produk pangan lempuk. Dalam pembuatan plastik biodegradable, senyawa lesitin sering digunakan. Lesitin, atau yang dikenal juga sebagai fofatidilkolin, merupakan senyawa yang bersifat hidrofilik pada bagian kepala, tetapi bersifat hidrofobik pada bagian ekor. Senyawa ini banyak ditemukan pada kuning telur dan kacang kedelai, dimana kadar lesitin dalam kuning telur 3 kali lebih banyak dari kacang kedelai. Penggunaan lesitin dalam pembuatan plastik biodegradable dikarenakan peran lesitin sebagai surfaktan, dimana lapisan yang dibuat oleh lesitin tidak mudah hancur, ringan, dan tidak bersifat volatile. Selain itu, lesitin juga tidak berbahaya, dapat ditemukan banyak di alam, tidak mahal, dan dapat terdegradasi (Anton et al., 2006; Singer dan Galan, 2011).

Dalam kemasan plastik biodegradable dapat ditambahkan bahan antimikroba. Kemasan antimikroba adalah sistem kemasan yang mampu mengendalikan, mengurangi, menghambat, atau memperlambat pertumbuhan mikroorganisme patogen dan mengurangi kontaminasi permukaan makanan. Penggunaan ekstrak tumbuh-tumbuhan diharapkan dapat mengembangkan penggunaan kemasan antimikroba. Beberapa usaha telah dibuat mengembangkan sistem kemasan yang aktif di mana bahan antimikroba di inkorporasikan ke dalam bahan polimer dan dilapisi pada permukaan makanan (Maizura et al., 2008).

Shorea leprosula (damar daging) merupakan salah satu tumbuhan yang dapat digunakan sebagai bahan baku dalam pembuatan plastik biodegradable. Selain itu, di dalam resin $S$. leprosula juga terkandung senyawa antimikroba sehingga plastik biodegradable yang dihasilkan juga memiliki sifat antimikroba (Norizan et al., 2012). Untuk meningkatkan aktivitas antimikroba dalam plastik biodegradable dari S. leprosula, dapat dilakukan penambahan senyawa kimia tambahan yang memiliki sifat antimikroba.

Udang sebagai salah satu produk perikanan yang memilliki sifat mudah busuk (highly perishable), maka penanganan yang baik mutlak diperlukan agar mutu udang tetap segar pada saat dikonsumsi. Penggunaan plastik biodegradable dengan matriks damar daging dan pati tapioka yang dilapisi senyawa bahan antimikroba merupakan cara untuk pengawetan udang. Oleh karena itu dilakukan penelitian tentang mutu udang yang dikemas menggunakan plastik biodegradable tersebut.

Penelitian ini bertujuan untuk mengetahui pengaruh matrikss damar daging dengan pati tapioka pada kemasan biodegradable dengan penambahan pelapis seng klorida, perak nitrat, propionat, propil paraben, terhadap 
mutu udang yang dikemas selama penyimpanan.

\section{METODE PENELITIAN}

\section{Bahan dan Peralatan}

Bahan-bahan yang digunakan adalah resin S. leprosula, etil asetat, kertas saring, $\mathrm{ZnCl}_{2}$, agar nutrient, $\mathrm{AgNO}_{3}$, lesitin, plastik polipropilen, udang. Alat-alat yang digunakan adalah pengaduk magnetik, gelas ukur, pipet, neraca analitik, gelas piala, ruang asam, oven, hot plate stirrer, botol gelap, gunting, dan alat-alat lainnya.

\section{Prosedur Penelitian}

\section{Penelitian Pendahuluan}

Preparasi sampel

Sampel damar daging (S. leprosula) dipotong-potong tipis, kemudian ditambahkan etil asetat $20 \% \mathrm{~b} / \mathrm{v}$ ke dalam gelas piala dan diaduk terus menerus menggunakan pengaduk magnet selama 24 jam pada suhu kamar. Suspensi yang terbentuk disaring menggunakan kertas saring. Filtrat yang merupakan biopolimer, disimpan dan dimasukkan ke dalam botol gelap untuk penggunaan selanjutnya.

\section{Preparasi kemasan biodegradable}

Dengan membuat larutan $\mathrm{ZnCl}_{2}$ dan $\mathrm{AgNO}_{3}$ masing-masing 1 gram ditambahkan ke dalam larutan biopolimer kemudian diaduk dengan pengaduk magnetik. Sebelumnya ditambahkan 10 gram lesitin. Kemudian kemasan dari pati dicelupkan selama 2 detik ke dalam larutan biopolimer dan dikeringkan dalam lemari asam untuk mendapatkan kemasan bioaktif.

\section{Aktivitas antibakteri kemasan bioaktif}

Kemasan yang sudah dicelupkan, ditempatkan ke dalam nutrient agar yang telah ditumbuhi oleh bakteri patogen dan diinkubasi pada suhu $37^{\circ} \mathrm{C}$ selama 24 jam, kemudian zona beningnya diukur. Kemasan dengan zona bening terbesar dipilih untuk penelitian utama.

\section{Penelitian Utama}

Prosedur untuk pembuatan kemasan biodegradable pada penelitian ini meliputi, sampel damar daging ( $S$. leprosula) dipotongpotong tipis, kemudian ditambahkan etil asetat $20 \% \mathrm{~b} / \mathrm{v}$ ke dalam gelas piala dan diaduk terus menerus menggunakan pengaduk magnet selama 24 jam pada suhu kamar. Suspensi yang terbentuk disaring menggunakan kertas saring. Filtrat yang merupakan biopolimer, disimpan dan dimasukkan kedalam botol gelap untuk penggunaan selanjutnya. Selanjutnya membuat larutan $\mathrm{ZnCl}_{2}$ dan $\mathrm{AgNO}_{3}$ masingmasing 1 gram ditambahkan 10 gram lesitin, kemudian ditambahkan ke dalam larutan biopolimer dan diaduk dengan pengaduk magnetik. Bioplastik pati tapioka dicelupkan ke dalam larutan biopolimer tersebut selama 2 detik dan diulangi sampai 3 kali, kemudian dikeringkan dalam lemari asam untuk mendapatkan kemasan biodegradable berlapis senyawa antimikroba.

Kemasan bioplastik dengan zona bening terbesar diaplikasikan terhadap produk pangan perikanan yaitu udang. Terdapat tiga perlakuan terhadap udang yaitu udang yang dicelupkan kloramfenikol (kontrol positif), udang yang dibungkus dengan plastik propilen (kontrol negatif), dan udang yang dibungkus dengan kemasan bioplastik matrikss resin damar dan pati tapioka yang dilapisi senyawa antimikroba. Kemudian udang disimpan pada suhu $40^{\circ} \mathrm{C}$ dalam refrigerator dan dilakukan analisis mutu setiap 2 hari sekali sampai 8 hari (0 hari, 2 hari, 4 hari, 6 hari, 8 hari). Analisis mutu yang dilakukan meliputi analisis mikrobiologi, yaitu uji Total Plate Count (TPC), uji Escherichia coli, Salmonella typhi, Vibrio cholerae dan pengujian kadar air.

Data dianalisis secara inferensial untuk menguji hipotesis penelitian dengan menggunakan analisis variansi (ANOVA) untuk rancangan faktorial 5 x 5 dengan dua kali ulangan, yang dilanjutkan dengan metode DMRT (Duncan Multiple Range Test).

\section{HASIL DAN PEMBAHASAN Penelitian Pendahuluan}

Dari perlakuan yang diberikan berupa penambahan variasi antimikroba pada plastik biodegradable yaitu damar, lesitin, $\mathrm{ZnCl}_{2}, \mathrm{AgNO}_{3}$, Propionat dan Propil paraben 
diperoleh hasil zona bening yang dihasilkan (millimeter), seperti terlihat pada Tabel 1.

Tabel 1. Hasil Zona Bening Uji Antimikroba (mm)

\begin{tabular}{|l|r|r|r|r|r|r|r|}
\hline \multirow{2}{*}{ Bakteri } & \multicolumn{7}{|c|}{ Jenis Kemasan* } \\
\cline { 2 - 8 } & $\mathrm{a}$ & \multicolumn{1}{c|}{$\mathrm{b}$} & \multicolumn{1}{c|}{$\mathrm{c}$} & $\mathrm{d}$ & $\mathrm{e}$ & $\mathrm{f}$ & $\mathrm{g}$ \\
\hline S. typhi & 0 & 63 & 78 & 73 & 0 & 0 & 0 \\
\hline $\begin{array}{l}\text { P. } \\
\text { aeruginosa }\end{array}$ & 0 & 70 & 117 & 118 & 0 & 90 & 0 \\
\hline V. cholerae & 0 & 67 & 73 & 63 & 0 & 0 & 0 \\
\hline S. aureus & 60 & 93 & 110 & 97 & 0 & 0 & 0 \\
\hline B. cereus & 58 & 63 & 97 & 77 & 0 & 0 & 0 \\
\hline E. Coli & 0 & 0 & 88 & 87 & 0 & 0 & 0 \\
\hline
\end{tabular}

*Ket: a. Damar; b. Damar+Lesitin+ZnCl 2 ; c.

Damar+Lesitin+AgNO 3 ; d. $\mathrm{AgNO}_{3}$; e. Propionat; f.

$\mathrm{ZnCl}_{2}$; g. Propil paraben

Dari tabel diperoleh bahwa kemasan bioplastik+damar+Lesitin $+\mathrm{ZnCl}_{2}$ bioplastik+damar+Lesitin+ $\mathrm{AgNO}_{3} \quad$ (c), dan bioplastik $+\mathrm{AgNO}_{3}$ (d) menunjukkan adanya aktivitas antimikroba dengan adanya zona bening pada seluruh media yang ditumbuhi bakteri, sehingga kemasan tersebut diuji lanjut pada penelitian utama.

\section{Penelitian Utama \\ Kadar Air}

Data hasil pengamatan terhadap kadar air udang dengan menggunakan kemasan dan lama simpan yang berbeda maka didapatkan hasil rata-rata yang dapat dilihat pada Tabel 2 dan Gambar 1.

Tabel 2. Data Kadar Air Udang Rata-rata (\%)

\begin{tabular}{|c|c|c|c|c|c|}
\hline \multirow{2}{*}{$\begin{array}{c}\text { Lama } \\
\text { Hari }\end{array}$} & \multicolumn{5}{|c|}{ Jenis kemasan* } \\
\cline { 2 - 6 } & $\mathrm{a}$ & $\mathrm{b}$ & $\mathrm{c}$ & $\mathrm{d}$ & $\mathrm{e}$ \\
\hline 0 & 71,40 & 71,88 & 72,42 & 70,81 & 70,90 \\
\hline 2 & 50,31 & 55,39 & 65,41 & 70,54 & 70,40 \\
\hline 4 & 50,25 & 51,64 & 59,14 & 70,30 & 70,31 \\
\hline 6 & 50,16 & 49,89 & 58,15 & 70,36 & 69,85 \\
\hline 8 & 50,12 & 49,74 & 57,55 & 70,65 & 69,76 \\
\hline
\end{tabular}

*Ket: a. $\mathrm{ZnCl}_{2}+$ Lesitin; b. $\mathrm{AgNO}_{3}$; c. $\mathrm{AgNO}_{3}+$ Lesitin; d. Kloramfenikol; e. Plastik Polipropilen (PP)

Kadar air udang yang dikemas dengan kemasan yang berbeda cenderung mengalami penurunan selama penyimpanan, namun untuk udang dengan perlakuan kloramfenikol dan tanpa penambahan antimikroba tidak menunjukkan adanya kecenderungan penurunan kadar air.
Hasil ANOVA menunjukkan bahwa kadar air udang dipengaruhi sangat nyata oleh kemasan dengan penambahan antimikroba yang berbeda, demikian juga pada faktor lama simpan dan interaksi keduanya. Hasil uji lanjut menggunakan DMRT menghasilkan data seperti ditunjukkan pada Tabel 3.

Tabel 3. Uji DMRT Kadar Air Udang

\begin{tabular}{|c|c|c|}
\hline \multirow{2}{*}{$\begin{array}{c}\text { Interaksi jenis kemasan } \\
\text { dan lama simpan }\end{array}$} & \multirow{2}{*}{ Rerata } & Notasi* \\
\hline & & $\alpha=0,01$ \\
\hline $\mathrm{AgNO}_{3}+\mathrm{L}, 8$ hari & 49,74 & $\mathrm{a}$ \\
\hline $\mathrm{AgNO}_{3}+\mathrm{L}, 6$ hari & 49,89 & $\mathrm{a}$ \\
\hline $\mathrm{ZnCl}_{2}+\mathrm{L}, 8$ hari & 50,12 & $\mathrm{a}$ \\
\hline $\mathrm{ZnCl}_{2}+\mathrm{L}, 6$ hari & 50,16 & $\mathrm{a}$ \\
\hline $\mathrm{ZnCl}_{2}+\mathrm{L}, 4$ hari & 50,25 & $\mathrm{a}$ \\
\hline $\mathrm{ZnCl}_{2}+\mathrm{L}, 2$ hari & 50,31 & $\mathrm{ab}$ \\
\hline $\mathrm{AgNO}_{3}+\mathrm{L}, 4$ hari & 51,64 & $\mathrm{abc}$ \\
\hline $\mathrm{AgNO}_{3}+\mathrm{L}, 2$ hari & 55,39 & $\mathrm{bc}$ \\
\hline $\mathrm{AgNO}_{3}, 4$ hari & 57,55 & $\mathrm{C}$ \\
\hline $\mathrm{AgNO}_{3}, 6$ hari & 58,15 & $\mathrm{c}$ \\
\hline $\mathrm{AgNO}_{3}, 4$ hari & 59,14 & c \\
\hline $\mathrm{AgNO}_{3}, 2$ hari & 65,41 & $\mathrm{~d}$ \\
\hline Plastik PP, 8 hari & 69,76 & de \\
\hline Plastik PP, 6 hari & 69,85 & de \\
\hline Kloramfenikol, 4 hr & 70,30 & de \\
\hline Plastik PP, 6 hari & 70,31 & de \\
\hline Kloramfenikol, $6 \mathrm{hr}$ & 70,36 & de \\
\hline Plastik PP, 2 hari & 70,40 & de \\
\hline Kloramfenikol, 2 hr & 70,54 & de \\
\hline Kloramfenikol, $8 \mathrm{hr}$ & 70,65 & de \\
\hline Kloramfenikol, 0 hr & 70,81 & $\mathrm{e}$ \\
\hline Plastik PP, $0 \mathrm{hr}$ & 70,90 & $\mathrm{e}$ \\
\hline $\mathrm{ZnCl}_{2}+\mathrm{L}, 0$ hari & 71,40 & $\mathrm{e}$ \\
\hline $\mathrm{AgNO}_{3}+\mathrm{L}, 0$ hari & 71,88 & $\mathrm{e}$ \\
\hline $\mathrm{AgNO}_{3}, 0$ hari & 72,42 & $\mathrm{e}$ \\
\hline
\end{tabular}

Ket: *Huruf yang sama menunjukkan berbeda tidak nyata; L: Lesitin

Hasil uji DMRT menunjukkan semua perlakuan jenis kemasan (bioplastik+damar+lesitin+ $+\mathrm{AgNO}_{3}$, bioplastik+damar+lesitin $+\mathrm{ZnCl}_{2}$, bioplastik + $\mathrm{AgNO}_{3}$ ), plastik $\mathrm{PP}$ dan pelapisan kloramfenikol) pada awal penyimpanan (0 hari) berbeda tidak nyata, artinya pada awal penyimpanan tidak ada pengaruh jenis kemasan terhadap kadar air udang. Mulai pada lama penyimpanan 2 hari sampai dengan 8 hari menunjukkan adanya pengaruh jenis kemasan bioplastik yang ditambah $\mathrm{AgNO}_{3}$ dan $\mathrm{ZnCl}_{2}$.

Secara umum bioplastik sangat menyerap air dibandingkan dengan plastik sintetis yang kedap air. Sifat ketahanan air terhadap 
bioplastik dapat diukur menggunakan uji swelling, yaitu prosentase penggembungan film oleh adanya air. Untuk mengurangi jumlah penyerapan air oleh bioplastik maka diperlukan zat atau bahan yang dapat mengurangi penyerapan air. Zat atau bahan yang biasa digunakan adalah khitosan dan pemlastis gliserol. Berdasarkan penelitian Sanjaya dan Puspita (2010), penambahan khitosan dan gliserol dapat digunakan untuk mengurangi penyerapan air oleh bioplastik yang dihasilkan.

Semakin kecil nilai swelling maka daya serap air bioplastik terhadap air juga semakin kecil. Semakin tinggi suhu pengeringan yang digunakan maka mempengaruhi penguapan kitosan atau gliserol dalam bioplastik, sehingga bioplastik yang dihasilkan mengandung sedikit kitosan dan mempengaruhi sifat bioplastik yaitu menjadi hidrofilik (Sanjaya dan Puspita, 2010). Secara umum apabila bioplastik dibuang/dilepaskan ke lingkungan akuatik seperti waduk, sungai, dan danau tidak akan menimbulkan masalah lingkungan. Karena pada dasarnya bioplastik tersusun atas senyawa - senyawa yang masih dapat didegradasi oleh lingkungan dan dapat dikembalikan ke alam.

$\mathrm{ZnCl}_{2}$ dan $\mathrm{AgNO}_{3}$ bersifat higroskopis, sehingga semakin lama waktu penyimpanan maka semakin banyak air yang terserap oleh jenis kemasan biodegradable yang ditambahkan $\mathrm{ZnCl}_{2}$ dan $\mathrm{AgNO}_{3}$ (Esterlita dan Herlina, 2015).

\section{Total Plate Count (TPC)}

Data hasil pengamatan terhadap total mikroba (total plate count, TPC) pada udang dengan menggunakan kemasan dan lama simpan yang berbeda didapatkan hasil ratarata yang dapat dilihat pada tabel 4 .

Tabel 4. Data TPC udang rata-rata $\left(\mathrm{x10}^{4}\right)$

\begin{tabular}{|c|r|r|r|r|r|}
\hline \multirow{2}{*}{$\begin{array}{c}\text { Lama } \\
\text { simpan }\end{array}$} & \multicolumn{6}{|c|}{ Jenis kemasan* } \\
\cline { 2 - 6 } & $\mathrm{a}$ & $\mathrm{b}$ & $\mathrm{c}$ & \multicolumn{1}{c|}{$\mathrm{d}$} & \multicolumn{1}{c|}{$\mathrm{e}$} \\
\hline 0 & 4.4 & 4,5 & 4.4 & 3.9 & 4.8 \\
\hline 2 & 4.1 & 4.2 & 3.9 & 0 & 6.9 \\
\hline 4 & 4.1 & 4.1 & 3.9 & 0 & 8.8 \\
\hline 6 & 4.3 & 4.0 & 4.0 & 0 & 10.9 \\
\hline 8 & 4.6 & 3.9 & 3.9 & 0 & 12.7 \\
\hline
\end{tabular}

*Ket: a. ZnCl2; b. AgNO3; c. AgNO3+Lesitin; d. Kloramfenikol; e. Plastik Polipropilen (PP)
Tabel 4 menunjukkan bahwa, TPC udang yang dikemas dengan kemasan bioplastik yang ditambah antimikroba $\left(\mathrm{ZnCl}_{2}+\right.$ Lesitin, $\mathrm{AgNO}_{3}+$ Lesitin dan $\mathrm{AgNO}_{3}$ ) cenderung tetap selama penyimpanan, namun untuk udang dengan perlakuan kloramfenikol cenderung mengalami penurunan TPC lalu tetap dan perlakuan plastik PP cenderung mengalami peningkatan TPC.

Hasil uji Hasil ANOVA menunjukkan bahwa nilai TPC udang dipengaruhi nyata oleh lama simpan dan dipengaruhi sangat nyata oleh jenis kemasan yang berbeda, dan interaksi kedua perlakuan. Hasil uji lanjut menggunakan DMRT menghasilkan data seperti ditunjukkan pada Tabel 5.

Tabel 5. Hasil Uji DMRT

\begin{tabular}{|c|c|c|}
\hline \multirow{2}{*}{$\begin{array}{l}\text { Interaksi jenis kemasan } \\
\text { dan lama simpan }\end{array}$} & \multirow{2}{*}{$\begin{array}{l}\text { Rerata } \\
\left(10^{4}\right)\end{array}$} & Notasi \\
\hline & & $\alpha=0,01$ \\
\hline Kloramfenikol, $2 \mathrm{hr}$ & 0 & $\mathrm{a}$ \\
\hline Kloramfenikol, $4 \mathrm{hr}$ & 0 & $\mathrm{a}$ \\
\hline Kloramfenikol, $6 \mathrm{hr}$ & 0 & $\mathrm{a}$ \\
\hline Kloramfenikol, $8 \mathrm{hr}$ & 0 & $\mathrm{a}$ \\
\hline Kloramfenikol, $0 \mathrm{hr}$ & 3,9 & $\mathrm{~b}$ \\
\hline $\mathrm{AgNO}_{3}+\mathrm{L}, 8$ hari & 3,9 & $\mathrm{~b}$ \\
\hline $\mathrm{AgNO}_{3}, 2$ hari & 3,9 & $\mathrm{~b}$ \\
\hline $\mathrm{AgNO}_{3}, 4$ hari & 3,9 & $\mathrm{~b}$ \\
\hline $\mathrm{AgNO}_{3}, 8$ hari & 3,9 & $\mathrm{~b}$ \\
\hline $\mathrm{AgNO}_{3}+\mathrm{L}, 6$ hari & 4.0 & $\mathrm{~b}$ \\
\hline $\mathrm{AgNO}_{3,6} 6$ hari & 4,0 & $\mathrm{~b}$ \\
\hline $\mathrm{ZnCl}_{2}+\mathrm{L}, 2$ hari & 4,1 & $\mathrm{~b}$ \\
\hline $\mathrm{AgNO}_{3}+\mathrm{L} 4$ hari & 4,1 & $\mathrm{~b}$ \\
\hline $\mathrm{ZnCl}_{2}+\mathrm{L}, 4$ hari & 4,1 & $\mathrm{~b}$ \\
\hline $\mathrm{AgNO}_{3}+\mathrm{L}, 2$ hari & 4,2 & $\mathrm{~b}$ \\
\hline $\mathrm{ZnCl}_{2}+\mathrm{L}, 6$ hari & 4,3 & $\mathrm{~b}$ \\
\hline $\mathrm{ZnCl}_{2}+, 0$ hari & 4,4 & $\mathrm{~b}$ \\
\hline $\mathrm{AgNO}_{3}, 0$ hari & 4,4 & $\mathrm{~b}$ \\
\hline $\mathrm{AgNO}_{3}+\mathrm{L}, 0$ hari & 4,5 & $\mathrm{bc}$ \\
\hline $\mathrm{ZnCl}_{2}+\mathrm{L} 8$ hari & 4,6 & $\mathrm{bc}$ \\
\hline Plastik PP, 0 hari & 4,8 & $\mathrm{bc}$ \\
\hline Plastik PP, 2 hari & 6,9 & $\mathrm{C}$ \\
\hline Plastik PP, 4 hari & 8,8 & $\mathrm{~d}$ \\
\hline Plastik PP, 6 hari & 10,9 & $\mathrm{e}$ \\
\hline Plastik PP, 8 hari & 12,7 & $\mathrm{f}$ \\
\hline
\end{tabular}

Keterangan: *Huruf yang sama menunjukkan berbeda tidak nyata; L: Lesitin

Hasil uji lanjutan DMRT interaksi jenis kemasan dan lama hari (Tabel 5) menunjukkan bahwa interaksi jenis kemasan dan lama simpan berbeda tidak nyata pada perlakuan kemasan dengan penambahan antimikroba ( $\mathrm{ZnCl}_{2}+\mathrm{L}$, $\mathrm{AgNO}+\mathrm{L}$ dan AgNO3) dan perlakuan pelapisan udang dengan 
kloramfenikol terhadap pertumbuhan mikroba secara menurut TPC pada udang. Sebagai kontrol positif kloramfenikol menunjukkan aktivitas antimikroba yang baik (tidak ada pertumbuhan pada lama simpan 2-8 hari), dan sebagai kontrol negatif Plastik PP menunjukkan adanya pertumbuhan total mikroba. Dari hasil tersebut diperoleh bahwa perlakuan yang terbaik adalah perlakuan penggunaan kloramfenikol yang merupakan kontrol positifnya, tetapi untuk perlakuan kemasan dengan penambahan antimikroba adalah seluruh kemasan bioplastik dengan penambahan antimikroba menghasilkan menunjukkan hasil yang sama baiknya dapat dalam menahan pertumbuhan total mikroba. Sebelum penerapan, aplikasi kemasan biodegradable dengan aktivitas antimikroba pada udang, diujikan dulu terhadap tujuh bakteri patogen yaitu, $S$. typhi, $P$. aeruginosa, V. cholera, S. aureus, B. cereus, dan E. coli. Dari hasil yang diperoleh bahwa kemasan plastik berbasis pati dan damar menunjukkan aktivitas antimikroba terhadap bakteri $S$. aureus dan $B$. cereus. Sedangkan untuk kemasan damar dengan lesitin dan perak nitrat atau seng klorida menunjukkan aktivitas antimikroba pada semua jenis bakterinya, sehingga dapat dikatakan bahwa penambahan perak nitrat dan seng klorida menunjukkan aktivitas antimikroba yang lebih baik.

Perak (Ag) merupakan agen antimikroba yang efektif dalam menghambat mikroorganisme patogen seperti virus, bakteri, dan mikroorganisme eukariotik dalam berbagai bidang yang berhubungan dengan kesehatan. Ion perak dapat memberi efek antimikroba pada konsentrasi yang rendah (Lee et al., 2006). Efek antimikroba dari perak telah lama diketahui dan berawal dari penggunaan ion perak. Kekuatan aktivitas antimikroba perak efektif untuk melawan sekitar 650 jenis bakteri. Konsentrasi submilimolar dari AgNO3 bersifat lethal untuk bakteri gram negatif dan bakteri gram positif. Ion perak dan unsur perak utuh dapat pula digunakan sebagai disinfektan (Lv et al., 2008).
Seng (Zn) diperlukan untuk fungsi normal sel makhluk hidup, tetapi pada konsentrasi tinggi, seng bisa menjadi penghambat atau beracun untuk kegiatan pertumbuhan, sehingga perlu didapatkan konsentrasi yang terbaik untuk mendapatkan aktivitas antimikroba yang optimal. Berdasarkan penelitian oleh Nair et al. (2006), ZnCl2 (seng klorida) menunjukkan aktivitas antibakteri terhadap beberapa bakteri seperti $P$. aeruginosa, $P$. vulgaris, $P$. mirabilis, $K$. pneumonia dan S. aureus.

Perak dan seng klorida sudah sejak lama dipakai sebagai antimikroba. Menurut ulasan yang disusun Perez et al. (2006), perak nitrat telah diizinkan oleh FDA sebagai antimikroba pada kemasan makanan. Pada penelitian sebelumnya pada yang menggunakan bioplastik aktif seperti yang digunakan dalam penelitian ini, telah dilakukan melakukan uji migrasi perak dan seng ke dalam daging cincang. Hasilnya menunjukkan bahwa perak tidak bermigrasi ke dalam daging cincang (Handy, 2013), sedangkan seng klorida dapat bermigrasi ke daging cincang. Konsentrasi seng dalam daging cincang yang dibungkus dengan bioplastik aktif yang mengandung seng dan disimpan selama 9 hari pada suhu $4^{\circ} \mathrm{C}$ adalah 20 ppm (Jane, 2015). Namun demikian, konsentrasi seng dalam daging cincang yang dikemas dengan bioplastik aktif masih di bawah batas yang diijinkan FAO yaitu 45mg/hari (FAO, 2002). Di dalam tubuh, seng merupakan mikronutrien yang berperan dalam aspek metabolisme seperti reaksi-reaksi yang berkaitan dengan sintesis dan degradasi karbohidrat, protein, lipid, dan asam nukleat (Almatsier, 2004), namun bila dikonsumsi berlebih, dapat menyebabkan degenerasi otot jantung. Kelebihan sampai sepuluh kali Angka Kecukupan Gizi (AKG) mempengaruhi metabolisme kolesterol, mengubah nilai lipoprotein, dan dapat mempercepat timbulnya aterosklerosis. Dosis sebanyak 2 gram atau lebih dapat menyebabkan muntah, diare, demam, kelelahan, anemia, dan gangguan reproduksi. Suplemen seng dapat menyebabkan keracunan, begitupun makanan yang asam dan disimpan di dalam kaleng yang dilapisi seng (Almatsier, 2004). 
Kloramfenikol efektif terhadap berbagai bakteri Gram-positif dan Gram-negatif, termasuk sebagian organisme anaerobik. Antibiotik memiliki cara kerja sebagai bakterisidal (membunuh bakteri secara langsung) atau bakteriostatik (menghambat pertumbuhan bakteri). Pada kondisi bakteriostatis, mekanisme pertahanan tubuh inang seperti fagositosis dan produksi antibodi biasanya akan merusak mikroorganisme. Jenis antibiotik kloramfenikol sebenarnya telah dilarang untuk digunakan pada budidaya perikanan, karena jenis antibiotik ini membahayakan kesehatan manusia.

Dari hasil pengamatan diperoleh bahwa kemasan $\mathrm{ZnCl}_{2}+$ lesitin dan $\mathrm{AgNO}_{3}+$ lesitin dan kemasan $+\mathrm{AgNO}_{3}$ dapat menahan pertumbuhan mikroba pada udang yang diujikan.

\section{Uji Escherichia coli}

Dari hasil analisis terhadap jumlah bakteri E. coli yang diujikan pada udang diperoleh bahwa tidak menunjukkan reaksi positif, yaitu adanya warna hijau terang (metallic green) pada media Eosin Methylene Blue (EMB). Media EMB mempunyai keistimewaan mengandung laktosa dan berfungsi untuk memilah mikroba yang memfermentasikan laktosa. Mikroba yang memfermentasi laktosa menghasilkan koloni dengan inti berwarna gelap dengan kilap logam. Sedangkan mikroba lain yang dapat tumbuh koloninya tidak berwarna. Adanya EMB membantu mempertajam perbedaan tersebut. Agar EMB merupakan media padat yang dapat digunakan untuk menentukan jenis bakteri $E$. coli dengan memberikan hasil positif dalam tabung. EMB yang menggunakan Eosin Metilen Blue sebagai indikator memberikan perbedaan yang nyata antara koloni yang meragikan laktosa dan yang tidak.

\section{Uji Salmonella typhi}

Hasil analisis uji Salmonella typhi pada udang dengan kemasan plastik bioplastik didapat bahwa tidak adanya reaksi yang menunjukkan keberadaan bakteri Salmonella typhi pada media Hectoen Enteric Agar (HEA).
Jika menunjukkan reaksi positif maka akan muncul koloni tunggal bewarna hijau. HEA merupakan media selektif-diferensial, media ini tergolong selektif karena terdiri dari bile salt yang berguna untuk menghambat pertumbuhan bakteri gram positif dan beberapa gram negatif, sehingga diharapkan bakteri yang tumbuh hanya Salmonella. Media ini digolongkan menjadi media diferensial karena dapat membedakan bakteri Salmonella dengan bakteri lainnya dengan cara memberikan tiga jenis karbohidrat pada media, yaitu laktosa, glukosa, dan salisin, dengan komposisi laktosa yang paling tinggi. Salmonella tidak dapat memfermentasi laktosa, sehingga asam yang dihasilkan hanya sedikit karena hanya berasal dari fermentasi glukosa saja. Hal ini menyebabkan koloni Salmonella akan berwarna hijau-kebiruan karena asam yang dihasilkannya bereaksi dengan indikator yang ada pada media HEA, yaitu fuksin asam dan bromotimol biru.

\section{Uji Vibrio cholerae}

Hasil analisis dengan menggunakan media Thiosulfate Citrate Bile Salt Sucrose (TCBS) agar, didapat bahwa tidak adanya hasil positif koloni yang berwarna kuning pada media yang menunjukkan bahwa pada bioplastik dengan penambahan antimikroba tidak menunjukkan adanya pertumbuhan $V$. Cholera. TCBS agar banyak digunakan untuk isolasi selektif $V$. cholerae dan Vibrio enteropatogenik lainnya. Warna kuning disebabkan oleh fermentasi sukrosa di media

\section{KESIMPULAN}

Berdasarkan hasil penelitian didapatkan bahwa kemasan pati dengan penambahan damar dan agen lain seperti seng klorida, perak nitrat dan lesitin dapat menurunkan kadar air dan menahan pertumbuhan mikroba pada udang yang diujikan. Pada awal penyimpanan tidak ada pengaruh jenis kemasan terhadap kadar air udang, dan mulai pada lama penyimpanan 2 hari sampai dengan 8 hari menunjukkan adanya pengaruh jenis kemasan bioplastik yang ditambah $\mathrm{AgNO}_{3}+$ Lesitin, $\mathrm{ZnCl}_{2}+$ Lesitin dan $\mathrm{AgNO}_{3}$. Kemasan dengan penambahan 
antimikroba $\left(\mathrm{ZnCl}_{2}+\right.$ Lesitin, $\mathrm{AgNO}_{3}+$ Lesitin dan $\mathrm{AgNO}_{3}$ ) dan pelapisan udang dengan kloramfenikol dapat menahan pertumbuhan mikroba yang sama baiknya.

Bakteri patogen E. coli, S. typhi, dan V. cholerae tidak terdapat pada udang yang dikemas dengan dalam bioplastik dengan penambahan $\mathrm{AgNO}_{3}+$ Lesitin, $\mathrm{ZnCl}_{2}+$ Lesitin dan $\mathrm{AgNO}_{3}$.

\section{DAFTAR PUSTAKA}

Almatsier, S., 2004. Prinsip Dasar Ilmu Gizi. PT Gramedia Pustaka Utama, Jakarta.

Anton, M., Nau, F., \& Nys, Y., 2006. Bioactive egg components and their potential uses. World's Poultry Sci. J., 62, pp. 429-38.

Bourtoom, T., 2007. Effect of some process parameters on the properties of edible film prepared from starches. Songkhla: Department of material product technology. Challenges and Opportunities. Food Technology, 51(2), pp. 61-73.

Esterlita, M.O., \& Herlina, N., 2015. Pengaruh penambahan aktivator $\mathrm{ZnCl}_{2}, \mathrm{KOH}$, dan $\mathrm{H}_{3} \mathrm{PO}_{4}$ dalam pembuatan karbon aktif dari pelepah aren (Arenga pinnata). Jurnal Teknik Kimia USU, 4(1), hal. 47-52.

[FAO] Food and Agriculture Organization. 2002. Human vitamin and mineral requirements. FAO, Bangkok.

Handy, 2013. Active biopackaging with antimicrobial activity from dammar resin and silver for fresh meat preservation. Jakarta, Fakultas Teknobiologi, Unika Atmajaya

Harris, H., 2001. Kemungkinan penggunaan edible film dari pati tapioka untuk pengemas lempuk. Jurnal Ilmu-Ilmu Pertanian Indonesia, 3(2), hal. 99-106.

Jane, G.M.R., 2015. An overview of the compostability of biodegradable plastics and its implications for the collection and treatment of organic wastes, s.l.: ISWAthe international solid waste association.

Lee, S.Y., Kim, H.J., Patel, R., Im, S.J., Kim, J.H., \& Min, B.R., 2006. Silver nanoparticles immobilized on thin film composite polyamide membrane: characterization, nanofiltration, antifouling properties. Polym. Adv. Technol., 18, pp. 562-568

Maizura, M., Fazilah, A., Norziah, M.H, \& Karim, A. A., 2008. Antibacterial activity of modified sago starch-alginate based edible film incorporated with lemongrass (Cymbopogon citratus) oil. International Food Research Journal, 15(2), pp. 233-236.

Nair, L.S., Bijoux, C., Trevor, S., \& Laurencin, C.T., 2006. Development of injectable thermogelling chitosan-inorganic phosphate solution for biomedical application. Social Biomaterial Meeting

Norizan, N., Ahmat, N., Mohamad, S.A.S., Nazri, N.A.A.M., Ramli, S.S.A., Kasim, S.N.M., Zain, W.Z.W.M., 2012. Total phenolic content, total flavonoid content, antioxidant and antimicrobial activities of Malaysian Shorea. Re. J. Med. Plant, pp. 1-9.

Perez, P.C., Regalado-González, C., RodríguezRodríguez, C.A., Barbosa-Rodríguez J. R., \& Villaseñor-Ortega, F., 2006. Incorporation of antimicrobial agents in food packaging films and coatings. In: Guevara-González RG and Torres-Pacheco L, (Eds.), Advances in Agricultural and Food Biotechnology, pp. 193-216.

Sanjaya, I.G., \& Puspita, T., 2010. Pengaruh penambahan khitosan dan plasticizer gliserol pada karakteristik plastik biodegradable dari pati limbah kulit singkong. Surabaya : Jurusan Teknik Kimia FTI-ITS.

Singer, A., \& Galan, E., 2011. Developments in Palygorskite-Sepiolite Research. Elsevier. South East Asia

Lv, Y., Liu, H., Wang, Z., Ha, L., Liu, J., Wang, Y., Du, G., Liu, D., Zhan, J., \& Wang, J., 2008. Antibiotic glass slide coated with silver nanoparticles and its antimicrobial capabilities. Polym. Adv. Technol. 19, pp. 1455-1460 


\section{BIODATA}

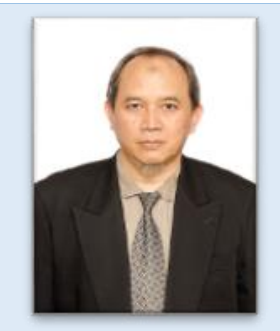

Dr. Ir. Iman Basriman, MSi., dilahirkan di Bandung, 16 Mei 1963. Pada tahun 1989 menyelesaikan studi S1 pada program studi Teknologi Pangan dan Gizi, IPB. Pada tahun 2001 menyelesaikan studi S2 pada program studi Teknologi Industri Pertanian, IPB. Pada tahun 2015 menyelesaikan studi S3 pada program studi Doktor Ekonomi Terapan, Unpad. Saat ini sebagai staf dosen Universitas Sahid pada program studi Teknologi Pangan 